Article

\title{
High Income Protects Whites but Not African Americans against Risk of Depression
}

\author{
Shervin Assari 1,2 (iD) \\ 1 Center for Research on Ethnicity, Culture, and Health (CRECH), School of Public Health, \\ University of Michigan, Ann Arbor, MI 48104, USA; assari@umich.edu; Tel.: +1-734-363-2678 \\ 2 Department of Psychiatry, University of Michigan, 4250 Plymouth Rd., Ann Arbor, MI 48109-2700, USA
}

Received: 18 March 2018; Accepted: 11 April 2018; Published: 23 April 2018

check for updates

\begin{abstract}
Background: Built on the Blacks' diminished return theory, defined as smaller effects of socioeconomic status (SES) on a wide range of health outcomes for African Americans compared to Whites, the current study compared African Americans and Whites for the association between household income and risk of lifetime, 12-month, and 30-day major depressive disorder (MDD). Methods: For the current cross-sectional study, we used data from the Collaborative Psychiatric Epidemiology Surveys (CPES), 2001-2003. With a nationally representative sampling, CPES included 4746 non-Hispanic African Americans and 7587 non-Hispanic Whites. The dependent variables were lifetime, 12-month, and 30-day MDD, measured using Composite International Diagnostic Interview (CIDI). The independent variable was household income. Age, gender, education, chronic medical conditions, and obesity were covariates. Race was the focal moderator. Logistic regression models were used to test the protective effects of household income against MDD in the overall sample and also by race. Results: In the overall sample, household income was inversely associated with the risk of 12-month and 30-day MDD. We found a significant interaction between race and household income on 12-month and 30-day MDD, suggesting a smaller protective effect of household income against MDD for African Americans compared to Whites. Conclusion: In line with the Blacks' diminished return theory, household income better protects Whites than African Americans against MDD. The contribution of diminished return of SES as an underlying mechanism behind racial disparities in health in the United States is often overlooked. Additional research is needed on why and how SES resources generate smaller health gain among minority groups.
\end{abstract}

Keywords: socioeconomic status; depression; major depressive disorder; ethnic health disparities; race; African Americans

\section{Introduction}

Longitudinal and cross-sectional studies have strongly established the protective effects of socioeconomic status (SES) on population health [1-6]. SES indicators such education [7], employment [8,9], and income [1,4,5] protect individuals against morbidity [10] and mortality [11-13]. Income has protective effects against risk of depression [14].

However, population sub-groups do not similarly gain health from their SES indicators [15-17]. Some of the sociodemographic factors that alter the effects of SES include age [18], gender [3,19-22], race [19-21], and their intersections [22]. This is in line with the Blacks' "diminished return" theory, suggesting that the protective effect of SES on health of populations is systemically smaller for African Americans in comparison to Whites [15,16,21]. Education [20], employment [23], and income [24] better reduce mortality and morbidity of the socially privileged than the socially disadvantaged group.

Research that shows SES effects are conditional by race $[25,26]$ suggest that it is race and SES not race or SES that cause racial disparities $[15,16]$. If it is race and SES not race or SES, then SES does 
not fully explain the effects of race, and for the elimination of racial disparities in health, more needs to be done than merely eliminating racial disparities in SES $[15,16]$. That is, the elimination of SES disparities will not fully eliminate the racial disparities in health.

Regarding the effects of high SES on major depressive disorder (MDD), a meta-analysis showed that the prevalence, incidence, and persistence of MDD is lower in high-SES individuals compared to low-SES individuals [27]. However, individual studies have shown mixed results regarding the protective effects of SES indicators against risk of MDD [19,22,28,29]. Studies have suggested that the protective effects of SES indicators such as education and income against MDD and depressive symptoms may be larger for Whites than non-Whites [19,22]. In line with this literature, some research has documented an increase in the risk of depression in high-SES African Americans [22,28].

Aims

The current study compared African Americans and Whites for the association between household income and lifetime, 12-month, and 30-day MDD.

\section{Methods}

\subsection{Design and Setting}

With a cross-sectional design, the current study used data from the Collaborative Psychiatric Epidemiology Surveys (CPES), 2001-2003. The CPES was conducted by the University of Michigan (UM, Ann Arbor, MI, USA). Although the CPES methods have been described in detail elsewhere [29], we briefly summarize the study methodology here.

CPES is composed of three national surveys: (1) the National Comorbidity Survey- Replication (NCS-R) [30], (2) the National Latino and Asian American Study (NLAAS) [31], and (3) the National Study of American Life (NSAL) [29]. The CPES data were collected by the University of Michigan (UM) Institute for Social Research (ISR), Ann Arbor.

\subsection{Sampling}

White and African American participants were recruited using the CPES core sampling. Core sampling of the CPES was a multistage stratified area probability sample that recruited a nationally representative household sample. All participants were adults (18 years of age and older). Participants were recruited from households in the coterminous 48 states. The sample was limited to individuals who were able to conduct an interview in English. This study did not include any institutionalized individuals. Thus, being in prisons, jails, nursing homes, and medical facilities were exclusion criteria [29]. African Americans and Whites in the CPES were selected from large cities, other urban areas, or rural areas [29]. The analysis for the current study included a total of 4746 non-Hispanic African Americans and 7587 non-Hispanic Whites.

\subsection{Ethics}

The CPES study protocol was approved by the University of Michigan (UM) Institutional Review Board (IRB \# B03-00004038-R1). Informed written consent was received from all participants. Data were kept anonymous. Participants were financially compensated for their time. Publicly available CPES data were downloaded from Interuniversity Consortium for Political and Social Research (ICPSR https: / / www.icpsr.umich.edu), located at the University of Michigan Institute for Social Research.

\subsection{Data Collection}

CPES collected data using structured interviews (survey questionnaires). Most of the data were collected using computer-assisted face-to-face interviews. Telephone interviews were only used for 
the remaining data collection. Interviews lasted between two hours on average. The overall response rate of the CPES is $69 \%$.

\subsection{Measures}

\subsubsection{Independent Variable}

Household income was self-reported. Income was treated as a continuous measure in this study. To increase interpretability of the income coefficients, we divided income by USD 10,000. So, our income coefficients reflect the effect of a USD 10,000 increase in income on odds of MDD.

\subsubsection{Dependent Variable}

Major Depressive Disorder (MDD). The presence of MDD (lifetime, 12-month, and 30-day) was evaluated using the World Mental Health (WMH) Composite International Diagnostic Interview (CIDI). The CIDI can be administered by trained interviewers who are not clinicians. Participants were assessed for meeting the DSM criteria for MDD. CIDI is frequently used for African Americans and Whites [32-36].

\subsubsection{Covariates}

Covariates in this study included demographic characteristics (age and gender), health (chronic medical conditions and obesity), and socioeconomic status (education). Age was operationalized as a continuous variable. Gender was conceptualized as a dichotomous variable (male 1 vs. female 0 ). The socioeconomic covariate included education, which was measured as an ordinal variable with the following four categories: (1) less than 11 years, (2) 12 years, (3) between 13 and 15 years, and (4) 16 years or more. Education was operationalized as a categorical variable [37]. Chronic medical conditions and obesity were health covariates. Participants indicated whether or not they were ever told by a doctor or health professional that they had chronic medical conditions, including heart diseases, hypertension, chronic lung disease, asthma, diabetes, peptic ulcer, epilepsy, and cancer. Chronic medical conditions were defined as the number of chronic medical conditions, with a potential range from 0 to 8 [38-40]. Obesity was defined as having a body mass index (BMI) equal to or larger than 30. BMI was calculated using participants' self-reported height and weight. The use of self-reported height and weight in the calculation of BMI has been validated [41,42].

\subsubsection{Moderator}

Race. Race was self-identified in the CPSE [43-46]. African-Americans were defined as Blacks without any ancestral ties to the Caribbean. Race was treated as a dichotomous variable, with Whites being the reference category. (African Americans $=1$ vs. Whites =0). All African Americans and Whites entered in this analysis were non-Hispanic.

\subsection{Statistical Analysis}

\subsubsection{Weights}

To accommodate the CPES's sampling weight, which was due to the multi-stage sampling design of the NCS-R, NSAL, and NLAAS, Stata 13.0 (Stata Corp., College Station, TX, USA) was applied for all our data analysis. This approach will consider applying the CPES sampling weights. We used Taylor series linearization to re-estimate our standard errors. To perform our subsample analyses, we applied sub-pop survey commands in Stata.

\subsubsection{Analytical Plan}

For descriptive purposes, we used mean (SE) and proportions (relative frequency). Bivariate analyses included independent sample $t$-test, Pearson Chi square, and Spearman correlation tests 
in the pooled sample and by race. For multivariable analysis, we used four logistic regression models. From independent sample $t$-test and Pearson Chi square tests, we only reported $p$-values. From Spearman correlation tests, we reported rho values. Adjusted odds ratios (OR), 95\% confidence intervals (CIs), and $p$-values were reported. In our logistic regression models, we used household income as the independent variable, MDD (lifetime, 12-month, and 30-day) as the dependent variable, and socio-demographics as covariates. Race was the focal moderator. The first two logistic regression models were estimated in the pooled sample composed of both African Americans and Whites. Model 1 did not include race by household income interaction. Model 2 included the race by household income interaction term. Subsequently, we estimated race-specific logistic regression models. Model 3 was estimated for Whites and Model 4 was calculated for African Americans.

\section{Results}

\subsection{Descriptive Statistics}

Table 1 provides a summary of the descriptive statistics in the overall sample and by race. African Americans had lower education and household income in comparison to Whites. African Americans had lower odds of MDD than Whites (Table 1).

Table 1. Summary of descriptive statistics in the overall sample and by race.

\begin{tabular}{|c|c|c|c|c|c|c|}
\hline \multirow{2}{*}{ Characteristics } & \multicolumn{2}{|r|}{ All } & \multicolumn{2}{|c|}{ Whites } & \multicolumn{2}{|c|}{ African Americans } \\
\hline & $\%$ & $95 \% \mathrm{CI}$ & $\%$ & $95 \%$ CI & $\%$ & $95 \% \mathrm{CI}$ \\
\hline \multicolumn{7}{|l|}{ Gender } \\
\hline Men & 52.00 & $50.72-53.28$ & 51.59 & $50.09-53.10$ & 54.68 & $53.34-56.02$ \\
\hline Women & 48.00 & $46.72-49.28$ & 48.41 & $46.90-49.91$ & 45.32 & $43.98-46.66$ \\
\hline \multicolumn{7}{|l|}{ Education $(\geq 12 \text { years })^{*, a}$} \\
\hline 0-11 years & 14.58 & $13.25-16.02$ & 13.18 & $11.57-14.98$ & 23.76 & $21.92-25.70$ \\
\hline 12 years & 32.01 & $29.66-34.45$ & 31.30 & $28.57-34.15$ & 36.66 & $35.11-38.23$ \\
\hline $13-15$ years & 27.76 & $26.30-29.27$ & 28.16 & $26.44-29.95$ & 25.14 & $23.55-26.80$ \\
\hline 16 years+ & 25.65 & 23.33-28.12 & 27.36 & $24.63-30.28$ & 14.44 & $12.74-16.33$ \\
\hline \multicolumn{7}{|l|}{ Obesity *,a } \\
\hline No & 75.35 & $74.09-76.58$ & 76.86 & $75.34-78.31$ & 65.52 & $64.03-66.97$ \\
\hline Yes & 24.65 & $23.42-25.91$ & 23.14 & $21.69-24.66$ & 34.48 & $33.03-35.97$ \\
\hline \multicolumn{7}{|l|}{ Lifetime Major Depressive Disorder *,a } \\
\hline No & 82.98 & $81.95-83.96$ & 81.98 & $80.85-83.06$ & 89.51 & $88.55-90.40$ \\
\hline Yes & 17.02 & 16.04-18.05 & 18.02 & $16.94-19.15$ & 10.49 & $9.60-11.45$ \\
\hline \multicolumn{7}{|l|}{ 12-Month Major Depressive Disorder *a } \\
\hline No & 93.14 & $92.59-93.66$ & 92.93 & $92.31-93.51$ & 94.52 & $93.74-95.21$ \\
\hline Yes & 6.86 & $6.34-7.41$ & 7.07 & $6.49-7.69$ & 5.48 & $4.79-6.26$ \\
\hline \multicolumn{7}{|l|}{ 30-Day Major Depressive Disorder *,a } \\
\hline No & 97.42 & 97.04-97.75 & 97.33 & $96.90-97.70$ & 98.01 & $97.50-98.42$ \\
\hline \multirow[t]{2}{*}{ Yes } & 2.58 & $2.25-2.96$ & 2.67 & $2.30-3.10$ & 1.99 & $1.58-2.50$ \\
\hline & Mean & $95 \%$ CI & Mean & $95 \%$ CI & Mean & $95 \% \mathrm{CI}$ \\
\hline Age (years) * & 43.09 & $42.37-43.82$ & 44.65 & $43.64-45.65$ & 40.78 & $38.66-42.90$ \\
\hline Chronic medical conditions (CMC) $*, b$ & 0.68 & $0.65-0.71$ & 0.73 & $0.70-0.77$ & 0.83 & $0.73-0.93$ \\
\hline Household Income (USD 10,000) *,b & 5.99 & $5.69-6.28$ & 6.34 & $5.92-6.76$ & 4.40 & $3.78-5.02$ \\
\hline
\end{tabular}

\subsection{Bivariate Correlations}

Table 2 presents the results of bivariate correlations in the pooled sample and by race. Household income showed negative correlation with 12-month and 30-day MDD in the pooled sample and White, but not African Americans (Table 2). 
Table 2. Spearman correlations in the pooled sample and by race.

\begin{tabular}{|c|c|c|c|c|c|c|c|c|c|c|}
\hline Characteristics & 1 & 2 & 3 & 4 & 5 & 6 & 7 & 8 & 9 & 10 \\
\hline \multicolumn{11}{|l|}{ All } \\
\hline 1 Race (African Americans) & 1.00 & & & & & & & & & \\
\hline 4 Chronic Medical Conditions & 0.05 & -0.01 & $0.37 *$ & 1.00 & & & & & & \\
\hline 5 Obesity & 0.09 & -0.02 & 0.05 & 0.17 * & 1.00 & & & & & \\
\hline 6 Education ( $\geq 12$ years) & $-0.11 *$ & -0.02 & -0.09 & $-0.12 *$ & -0.06 & 1.00 & & & & \\
\hline 912-Month Major Depressive Disorder (MDD) & -0.02 & -0.08 & -0.08 & 0.03 & 0.01 & 0.00 & -0.06 & 0.58 * & 1.00 & \\
\hline 10 30-Day Major Depressive Disorder (MDD) & -0.01 & -0.05 & -0.03 & 0.02 & 0.00 & -0.02 & -0.05 & 0.34 * & $0.58^{*}$ & 1.00 \\
\hline \multicolumn{11}{|l|}{ Whites } \\
\hline 2 Gender (Women) & & 1.00 & & & & & & & & \\
\hline 3 Age & & -0.05 & 1.00 & & & & & & & \\
\hline 4 Chronic Medical Conditions & & -0.01 & $0.37 *$ & 1.00 & & & & & & \\
\hline 9 12-Month Major Depressive Disorder (MDD) & & -0.09 & -0.08 & 0.03 & 0.02 & -0.01 & -0.07 & 0.57 * & 1.00 & \\
\hline 10 30-Day Major Depressive Disorder (MDD) & & -0.05 & -0.04 & 0.01 & 0.01 & -0.02 & -0.06 & $0.33 *$ & $0.57^{*}$ & 1.00 \\
\hline \multicolumn{11}{|l|}{ African Americans } \\
\hline 2 Gender (Women) & & 1.00 & & & & & & & & \\
\hline 3 Age & & -0.01 & 1.00 & & & & & & & \\
\hline 4 Chronic Medical Conditions & & -0.02 & 0.36 & 1.00 & & & & & & \\
\hline 5 Obesity & & $-0.10 *$ & 0.04 & $0.13 *$ & 1.00 & & & & & \\
\hline 6 Education ( $\geq 12$ years) & & -0.06 & -0.09 & -0.07 & -0.03 & 1.00 & & & & \\
\hline 7 Household Income (USD 10,000) & & 0.12 * & -0.02 & $-0.13 *$ & -0.08 & $0.37^{*}$ & 1.00 & & & \\
\hline 8 Lifetime Major Depressive Disorder (MDD) & & -0.06 & -0.09 & -0.03 & 0.00 & 0.04 & -0.01 & 1.00 & & \\
\hline 9 12-Month Major Depressive Disorder (MDD) & & -0.06 & -0.09 & 0.02 & -0.02 & 0.05 & 0.00 & $0.65 *$ & 1.00 & \\
\hline 10 30-Day Major Depressive Disorder (MDD) & & -0.04 & -0.02 & 0.02 & -0.07 & 0.01 & 0.02 & $0.39 *$ & $0.60 *$ & 1.00 \\
\hline
\end{tabular}

\subsection{Logistic Regressions in the Overall Sample}

Table 3 presents the results of three sets of logistic regression models in the pooled sample. Both models have household income as the independent variable, and lifetime, 12-month, and 30-day MDD as the dependent variables. Model 1 only included the main effects. Model 2 also included the race by household income interaction term. Model 1 showed that high household income was associated with lower odds of MDD above and beyond the covariates. Model 2 also showed an interaction between race and household income, suggesting that the protective effects of household income against 12-month and 30-day MDD are smaller for African Americans relative to Whites (Table 3).

Table 3. Summary of logistic regressions between household income and major depressive disorder (MDD) in the pooled sample.

\begin{tabular}{|c|c|c|c|c|}
\hline \multirow[t]{2}{*}{ Characteristics } & \multicolumn{2}{|c|}{$\begin{array}{c}\text { Model } 1 \\
\text { Main Effects }\end{array}$} & \multicolumn{2}{|c|}{$\begin{array}{c}\text { Model } 2 \\
\text { Model } 1 \text { + Interactions }\end{array}$} \\
\hline & B & $95 \% \mathrm{CI}$ & B & $95 \% \mathrm{CI}$ \\
\hline \multicolumn{5}{|l|}{ Lifetime MDD } \\
\hline Race (African Americans) & $0.57 * * *$ & $0.43-0.74$ & $0.55 * * *$ & $0.40-0.74$ \\
\hline Gender (Women) & $0.60 * * *$ & $0.53-0.69$ & $0.60 * * *$ & $0.53-0.69$ \\
\hline Age & $0.99 *$ & $0.99-1.00$ & $0.99 *$ & $0.99-1.00$ \\
\hline Chronic Medical Conditions & $1.08 \#$ & $0.99-1.16$ & $1.08 \#$ & $0.99-1.16$ \\
\hline Obesity & $1.28 * * *$ & $1.12-1.45$ & $1.28 * * *$ & $1.12-1.45$ \\
\hline \multicolumn{5}{|l|}{ Education ( $\geq 12$ years) } \\
\hline \multicolumn{5}{|l|}{$0-11$ years } \\
\hline 12 years & 1.03 & $0.77-1.39$ & 1.03 & $0.77-1.39$ \\
\hline $13-15$ years & 1.15 & $0.94-1.40$ & 1.15 & $0.94-1.40$ \\
\hline 16 years+ & $1.24 \#$ & $0.97-1.57$ & $1.24 \#$ & $0.97-1.57$ \\
\hline Household Income (USD 10,000) & 1.00 & $0.99-1.02$ & 1.00 & $0.99-1.02$ \\
\hline Household Income (USD 10,000) $\times$ Race & - & - & 1.01 & $0.97-1.05$ \\
\hline Intercept & $0.52 * * *$ & $0.39-0.69$ & $0.52 * * *$ & $0.39-0.69$ \\
\hline
\end{tabular}


Table 3. Cont.

\begin{tabular}{|c|c|c|c|c|}
\hline \multirow[t]{2}{*}{ Characteristics } & \multicolumn{2}{|c|}{$\begin{array}{c}\text { Model 1 } \\
\text { Main Effects }\end{array}$} & \multicolumn{2}{|c|}{$\begin{array}{cl}\text { Model 2 } \\
\text { Model 1 + Interactions }\end{array}$} \\
\hline & B & $95 \%$ CI & B & $95 \%$ CI \\
\hline \multicolumn{5}{|l|}{ 12-Month MDD } \\
\hline Race (African Americans) & $0.65 *$ & $0.47-0.91$ & $0.49^{* * *}$ & $0.34-0.73$ \\
\hline Gender (Women) & $0.56^{* * *}$ & $0.47-0.66$ & $0.56 * * *$ & $0.47-0.66$ \\
\hline Age & $0.98^{* * *}$ & $0.97-0.98$ & $0.98^{* * *}$ & $0.97-0.98$ \\
\hline Chronic Medical Conditions & $1.26^{* * *}$ & $1.10-1.44$ & $1.26^{* * *}$ & $1.10-1.44$ \\
\hline Obesity & 1.14 & $0.92-1.41$ & 1.14 & $0.92-1.41$ \\
\hline \multicolumn{5}{|l|}{ Education $(\geq 12$ years $)$} \\
\hline \multicolumn{5}{|l|}{$0-11$ years } \\
\hline 12 years & 0.72 & $0.49-1.07$ & 0.72 & $0.49-1.07$ \\
\hline $13-15$ years & 0.81 & $0.62-1.04$ & $0.80 \#$ & $0.62-1.04$ \\
\hline 16 years + & 0.92 & $0.67-1.26$ & 0.91 & $0.67-1.26$ \\
\hline Household Income (USD 10,000) & $0.96^{* *}$ & $0.93-0.99$ & $0.96^{* *}$ & $0.93-0.99$ \\
\hline Household Income $($ USD 10,000$) \times$ Race & - & - & $1.07 *$ & $1.00-1.14$ \\
\hline Intercept & $0.54^{* * *}$ & $0.39-0.75$ & $0.55^{* * *}$ & $0.39-0.76$ \\
\hline \multicolumn{5}{|l|}{ 30-Day MDD } \\
\hline Race (African Americans) & 0.69 & $0.43-1.10$ & 0.43 & $0.23-0.79$ \\
\hline Gender (Women) & $0.56^{* * *}$ & $0.41-0.77$ & 0.56 & $0.41-0.77$ \\
\hline Age & $0.98^{* *}$ & $0.98-0.99$ & 0.98 & $0.98-0.99$ \\
\hline Chronic Medical Conditions & 1.09 & $0.94-1.26$ & 1.09 & $0.94-1.26$ \\
\hline Obesity & 1.42 & $0.78-2.62$ & 1.43 & $0.78-2.62$ \\
\hline \multicolumn{5}{|l|}{ Education ( $\geq 12$ years) } \\
\hline \multicolumn{5}{|l|}{$0-11$ years } \\
\hline 12 years & $0.55 *$ & $0.31-0.97$ & 0.55 & $0.31-0.97$ \\
\hline $13-15$ years & $0.55 *$ & $0.33-0.92$ & 0.55 & $0.33-0.92$ \\
\hline 16 years+ & 0.82 & $0.45-1.47$ & 0.81 & $0.45-1.46$ \\
\hline Household Income (USD 10,000) & $0.94 *$ & $0.89-0.99$ & 0.94 & $0.89-0.99$ \\
\hline Household Income (USD 10,000) $\times$ Race & - & - & 1.12 & $1.00-1.26$ \\
\hline Intercept & $0.18^{* * *}$ & $0.10-0.34$ & 0.19 & $0.10-0.35$ \\
\hline
\end{tabular}

\subsection{Logistic Regressions by Race}

Table 4 provides a summary of the results of two logistic regression models specific to Whites and African Americans. Model 3 showed that in Whites, high household income was associated with lower odds of 12-month and 30-day MDD. Model 4 showed that in African Americans, household income was not associated with odds of 12-month or 30-day MDD (Table 4).

Table 4. Summary of logistic regressions between household income and major depressive disorder (MDD) in Whites and African Americans.

\begin{tabular}{ccccc}
\hline Characteristics & \multicolumn{2}{c}{$\begin{array}{c}\text { Model 1 } \\
\text { Whites }\end{array}$} & \multicolumn{2}{c}{$\begin{array}{c}\text { Model 2 } \\
\text { African Americans }\end{array}$} \\
\hline & B & $\mathbf{9 5 \%}$ CI & B & $\mathbf{9 5 \% ~ C I ~}$ \\
\hline Lifetime MDD & & & & \\
Gender (Women) & $0.60^{* * *}$ & $0.52-0.69$ & $0.69 \#$ & $0.46-1.05$ \\
Age & $0.99 *$ & $0.99-1.00$ & $0.99 \#$ & $0.98-1.00$ \\
Chronic Medical Conditions & $1.08 \#$ & $0.99-1.17$ & 1.03 & $0.82-1.30$ \\
Obesity & $1.30^{* * *}$ & $1.14-1.47$ & 0.84 & $0.55-1.27$ \\
Education $(\geq 12$ years) & & & & \\
0-11 years & & & & \\
12 years & 1.02 & $0.75-1.38$ & 1.48 & $0.70-3.13$ \\
13-15 years & 1.13 & $0.92-1.39$ & 1.56 & $0.73-3.33$ \\
16 years+ & $1.23 \#$ & $0.96-1.58$ & 1.32 & $0.64-2.75$ \\
Intercept & 1.00 & $0.99-1.02$ & 1.00 & $0.96-1.04$ \\
Household 1ncome (USD 10,000) & $0.52 * * *$ & $0.38-0.69$ & $0.30 * * *$ & $0.13-0.71$ \\
\hline
\end{tabular}


Table 4. Cont

\begin{tabular}{|c|c|c|c|c|}
\hline \multirow[t]{2}{*}{ Characteristics } & \multicolumn{2}{|c|}{$\begin{array}{l}\text { Model } 1 \\
\text { Whites }\end{array}$} & \multicolumn{2}{|c|}{$\begin{array}{c}\text { Model } 2 \\
\text { African Americans }\end{array}$} \\
\hline & B & $95 \%$ CI & B & $95 \%$ CI \\
\hline \multicolumn{5}{|l|}{ 12-Month MDD } \\
\hline Gender (Women) & $0.51 *$ & $0.28-0.92$ & $0.56^{* * *}$ & $0.47-0.67$ \\
\hline Age & $0.98 *$ & $0.96-0.99$ & $0.98^{* * *}$ & $0.97-0.98$ \\
\hline Chronic Medical Conditions & 1.31 & $0.91-1.87$ & $1.26^{* *}$ & $1.09-1.45$ \\
\hline Obesity & 0.76 & $0.43-1.34$ & 1.16 & $0.93-1.44$ \\
\hline \multicolumn{5}{|l|}{ Education ( $\geq 12$ years $)$} \\
\hline \multicolumn{5}{|l|}{$0-11$ years } \\
\hline 12 years & 1.55 & $0.61-3.95$ & $0.70 \#$ & $0.47-1.06$ \\
\hline $13-15$ years & 1.57 & $0.59-4.20$ & $0.78 \#$ & $0.60-1.03$ \\
\hline 16 years+ & 2.03 & $0.68-6.10$ & 0.89 & $0.65-1.23$ \\
\hline Household Income (USD 10,000) & 1.01 & $0.93-1.09$ & $0.96^{* *}$ & $0.93-0.99$ \\
\hline Intercept & $0.19^{* * *}$ & $0.06-0.56$ & $0.55^{* * *}$ & $0.39-0.78$ \\
\hline \multicolumn{5}{|l|}{ 30-Day MDD } \\
\hline Gender (Women) & 0.56 & $0.41-0.78$ & $0.40 *$ & $0.18-0.93$ \\
\hline Age & 0.98 & $0.98-0.99$ & 0.99 & $0.97-1.02$ \\
\hline Chronic Medical Conditions & 1.08 & $0.93-1.26$ & 1.20 & $0.76-1.90$ \\
\hline Obesity & 1.49 & $0.81-2.76$ & $0.31 *$ & $0.11-0.87$ \\
\hline \multicolumn{5}{|l|}{ Education ( $\geq 12$ years) } \\
\hline \multicolumn{5}{|l|}{$0-11$ years } \\
\hline 12 years & 0.54 & $0.30-0.97$ & 0.92 & $0.31-2.77$ \\
\hline $13-15$ years & 0.52 & $0.31-0.89$ & 1.83 & $0.52-6.43$ \\
\hline 16 years+ & 0.81 & $0.44-1.48$ & 0.74 & $0.11-5.17$ \\
\hline Household Income (USD 10,000) & 0.94 & $0.89-0.99$ & 1.03 & $0.93-1.14$ \\
\hline Intercept & 0.19 & $0.10-0.35$ & $0.06^{* *}$ & $0.01-0.31$ \\
\hline
\end{tabular}

$\# p<0.1,{ }^{*} p<0.05,{ }^{* *} p<0.01,{ }^{* * *} p<0.001$.

\section{Discussion}

Built on the Blacks' diminished return theory $[15,16]$, the current study aimed to explore racial variation in the association between household income and 12-month and 30-day MDD. Our findings showed that while higher household income is associated with lower risk of 12-month and 30-day MDD overall, this health gain is disproportionate and unequal for Whites and African Americans.

By documenting the diminished mental health returns of household income for African Americans compared to Whites, our results support the Blacks' diminished return theory $[15,16]$. Previously, smaller health effects of education, employment, and income were shown for physical health outcomes such as chronic disease and mortality in African Americans relative to Whites [20,21,23]. For instance, a recent study showed smaller protective effects of income on chronic medical conditions for African Americans compared to Whites [24]. The life expectancy gain that is expected to follow employment is smaller for African Americans compared to Whites [23]. Similar differential effects of education on health behaviors such as drinking between Whites and African Americans are shown [21]. In addition to economic resources, psychological assets such as affect, coping, sleep, self-rated health, and self-efficacy better serve the health of Whites than African Americans [47-57].

Blacks' diminished return theory has attributed the diminished return of African Americans to the discrimination and structural racism that are embedded in the fabric of American society. American society functions in a way that constantly maximizes the benefits of Whites, with the unintended consequence of minimum health return for non-Whites including African Americans, Latinos, and Native Americans [15,16,23].

The results do not suggest that African Americans have a tendency to mismanage their economic resources such as income, or that Whites more effectively use their resources. Instead, we argue that the American social structure is failing the African American families, even high SES African American families who have successfully climbed the social ladder and earn high income. Regardless of their 
ambitions, the U.S. society makes them pay extra psychological costs for their social mobility. This is particularly shown in the studies showing poor mental health of high SES African Americans $[19,58]$.

One major contribution of this study is to the theoretical models that are commonly used for health disparities research. In line with the Blacks' diminished return theory, at least some of the disparities are not due to differential exposures, but differential effects of the very same exposures [15,16]. Unfortunately, differential effects of socioeconomic factors between African Americans and Whites is traditionally overlooked [20,21]. We believe that without an assumption that the protective effects of SES indicators are universal, researchers should systemically explore interactions between race and resources on health $[15,16]$. Another theoretical contribution of this study is that it may not be African Americans but Whites whose health declines more rapidly due to low SES. Several existing theories such as Double Jeopardy [28,59], Triple Jeopardy [60], Multiple Jeopardy [61], and Multiple Disadvantage [62] conceptualize minority status as a vulnerable status, meaning that minority populations' health is more strongly dependent upon the presence or absence of very same risk or protective factor [61].

This is not the first study to show that race alters the health effects of SES indicators; however, most of this literature has focused on physical health outcomes such as mortality [63-67]. Relative to physical health outcomes [63-67], less is known about differential gains that follow SES indicators such as income on depression.

Similar to our findings, there is some research $[19,21,63,64,68]$ showing that SES does not explain the effect of race on health, but interacts with race on health [39]. In this view, race limits how much individuals and groups can benefit from the very same SES resource $[15,16]$. These patterns will result in high levels of racial disparities in high levels of SES [39,60].

A greater differential effect of education is shown than the differential effects of income. This is partially because given the racism in the labor market and segregation, education is more likely than income to generate different outcomes [69-72]. Racial inequity in pay causes differential health gains of education and employment by race $[60,71]$. The current study shows that the same racial gap exists between Whites and African Americans in how they can use their income to gain mental health. The low mental health gain of high-SES African Americans may be because high-SES African Americans are commonly more discriminated against than low-SES African Americans [72].

\subsection{Implications}

Our findings have policy and public health implications. Policies and programs should also aim to reduce the diminished returns of African Americans as a strategy to eliminate health disparities [15,16]. Addressing health disparities should go beyond merely equalizing access to the SES resources or reducing extra risk factors in the lives of minorities $[15,16]$.

The diminished health return of very same SES resources should be regarded as a major contributor of racial health disparities in the USA [73-76]. Policies that merely focus on a universal increase of all populations to SES indicators may widen the existing health disparities. Policy makers and program planners who are interested in eliminating the persisting racial health disparities in the USA should think beyond equalizing access to resources across populations. Tailored programs may be needed to ensure that all social groups equally benefit from the very same resources, regardless of their race and color. Policy and program evaluations should also consider the evaluation of the same policy or program by race, in order to understand how the very same policy is affecting population sub-groups, and whether our interventions are widening the existing gaps or not.

\subsection{Limitations}

Our study had its own limitations. Due to the cross-sectional design, the current study does not allow the establishment of causal associations between household income and CMC. Not only SES impacts mental health; poor mental health may interfere with productivity and income generation. Future research should also consider the risk of reverse causality between MDD and household. 
Another potential limitation of the current study is omitted confounders. We did not include several factors such as insurance, health care use, and history of encounters with the mental health care system. Similarly, this study was limited to individual characteristics. Future research should include higher-level SES indicators that reflect policy and communities for Whites and African Americans. Similar to other studies that compare racial groups for the effects of the same variable, differential validity may be a threat. MDD may be of different severity in Whites and African Americans [77].

\section{Conclusions}

To conclude, race was found to alter the magnitude of the association between household income and 12-month and 30-day MDD in the U.S. The effect of race is not just on the amount of SES indicators such as income, but also on how SES indicators impact the health of individuals. This may be because race is a very important social construct in the United States and shapes treatment by society and access to the opportunity structure.

Acknowledgments: Shervin Assari is partially supported by the Heinz C. Prechter Bipolar Research Fund and the Richard Tam Foundation at the University of Michigan Depression Center. This research is supported by National Institute of Mental Health Research Grants MH06220, MH62207, MH62209, HD049142 and RWJ DA18715 with generous support from SAMHSA and OBSSR. The National Survey of American Life (NSAL) was supported by the National Institute of Mental Health (U01-MH57716) with supplemental support from the National Institutes of Health Office of Behavioral and Social Science Research; National Institute on Aging (5R01 AG02020282) with supplemental support from the National Institute on Drug Abuse; and the University of Michigan. Preparation of this article was also aided by grants from the National Institute of Mental Health (1P01 MH58565, 1T32 MH67555, and 5TMH16806). This publication was also made possible by Grant Number 1KL2RR025015-01 from the National Center for Research Resources (NCRR), a component of the National Institutes of Health (NIH) and NIH Roadmap for Medical Research.

Conflicts of Interest: The author declares no conflict of interest.

\section{References}

1. Dowd, J.B.; Albright, J.; Raghunathan, T.E.; Schoeni, R.F.; Leclere, F.; Kaplan, G.A. Deeper and wider: Income and mortality in the USA over three decades. Int. J. Epidemiol. 2011, 40, 183-188. [CrossRef] [PubMed]

2. Marmot, M.G.; Shipley, M.J. Do socioeconomic differences in mortality persist after retirement? 25 year follow up of civil servants from the first Whitehall study. Br. Med. J. 1996, 313, 1170-1180. [CrossRef]

3. Morris, J.K.; Cook, D.G.; Shaper, A.G. Loss of employment and mortality. Br. Med. J. 1994, 308, $1135-1139$. [CrossRef]

4. Van Groenou, M.I.B.; Deeg, D.J.; Penninx, B.W. Income differentials in functional disability in old age: Relative risks of onset, recovery, decline, attrition and mortality. Aging Clin. Exp. Res. 2003, 15, 174-183. [CrossRef]

5. Berkman, C.S.; Gurland, B.J. The relationship among income, other socioeconomic indicators, and functional level in older persons. J. Aging Health 1998, 10, 81-98. [CrossRef] [PubMed]

6. Burgard, S.A.; Elliott, M.R.; Zivin, K.; House, J.S. Working conditions and depressive symptoms: A prospective study of US adults. J. Occup. Environ. Med. 2013, 55, 1007-1014. [CrossRef] [PubMed]

7. Baker, D.P.; Leon, J.; Smith Greenaway, E.G.; Collins, J.; Movit, M. The education effect on population health: A reassessment. Popul. Dev. Rev. 2011, 37, 307-332. [CrossRef] [PubMed]

8. Eliason, M. Alcohol-related morbidity and mortality following involuntary job loss: Evidence from Swedish register data. J. Stud. Alcohol Drugs 2014, 75, 35-46. [CrossRef] [PubMed]

9. Noelke, C.; Beckfield, J. Recessions, job loss, and mortality among older US adults. Am. J. Public Health 2014, 104, e126-e134. [CrossRef] [PubMed]

10. Herd, P.; Goesling, B.; House, J.S. Socioeconomic position and health: The differential effects of education versus income on the onset versus progression of health problems. J. Health Soc. Behav. 2007, 48, 223-238. [CrossRef] [PubMed]

11. Hummer, R.A.; Lariscy, J.T. Educational attainment and adult mortality. In International Handbook of Adult Mortality; Springer: Dordrecht, The Netherlands, 2011; pp. 241-261.

12. Masters, R.K.; Hummer, R.A.; Powers, D.A. Educational differences in US adult mortality a cohort perspective. Am. Soc. Rev. 2012, 77, 548-572. [CrossRef] [PubMed] 
13. Brown, D.C.; Hayward, M.D.; Montez, J.K.; Hummer, R.A.; Chiu, C.T.; Hidajat, M.M. The significance of education for mortality compression in the United States. Demography 2012, 49, 819-840. [CrossRef] [PubMed]

14. Lorant, V.; Deliege, D.; Eaton, W.; Robert, A.; Philippot, P.; Ansseau, M. Socioeconomic inequalities in depression: A meta-analysis. Am. J. Epidemiol. 2003, 157, 98-112. [CrossRef] [PubMed]

15. Assari, S. Health Disparities Due to Diminished Return among Black Americans: Public Policy Solutions. Soc. Issues Policy Rev. 2018, 12, 112-145. [CrossRef]

16. Assari, S. Unequal gain of equal resources across racial groups. Int. J. Health Policy Manag. 2017, 6, 1-6. [CrossRef] [PubMed]

17. Assari, S.; Thomas, A.; Caldwell, C.H.; Mincy, R.B. Blacks' Diminished Health Return of Family Structure and Socioeconomic Status; 15 Years of Follow-up of a National Urban Sample of Youth. J. Urban Health 2017. [CrossRef] [PubMed]

18. Roelfs, D.J.; Shor, E.; Davidson, K.W.; Schwartz, J.E. Losing life and livelihood: A systematic review and meta-analysis of unemployment and all-cause mortality. Soc. Sci. Med. 2011, 72, 840-854. [CrossRef] [PubMed]

19. Assari, S. Combined racial and gender differences in the long-term predictive role of education on depressive symptoms and chronic medical conditions. J. Racial Ethn. Health Disparit. 2016, 4, 385-396. [CrossRef] [PubMed]

20. Assari, S.; Lankarani, M.M. Race and urbanity alter the protective effect of education but not income on mortality. Front. Public Health 2016, 4. [CrossRef] [PubMed]

21. Assari, S.; Lankarani, M.M. Education and alcohol consumption among older Americans. Black-White Differences. Front. Public Health 2016, 4. [CrossRef] [PubMed]

22. Assari, S. Social Determinants of Depression: The Intersections of Race, Gender, and Socioeconomic Status. Brain Sci. 2017, 7, 156. [CrossRef] [PubMed]

23. Assari, S. Life expectancy gain due to employment status depends on race, gender, education, and their intersections. J. Racial Ethn. Health Disparit. 2017. [CrossRef] [PubMed]

24. Assari, S. The Benefits of Higher Income in Protecting against Chronic Medical Conditions Are Smaller for African Americans than Whites. Healthcare 2018, 6, 2. [CrossRef] [PubMed]

25. Steenland, K.; Henley, J.; Thun, M. All-cause and cause-specific death rates by educational status for two million people in two American Cancer Society cohorts, 1959-1996. Am. J. Epidemiol. 2002, 156, 11-21. [CrossRef] [PubMed]

26. Montez, J.K.; Hayward, M.D.; Brown, D.C.; Hummer, R.A. Why is the educational gradient of mortality steeper for men? J. Gerontol. Ser. B Psychol. Sci. Soc. Sci. 2009, 64, 625-634. [CrossRef] [PubMed]

27. Lorant, V.; Deliège, D.; Eaton, W.; Robert, A.; Philippot, P.; Ansseau, M. Socioeconomic inequalities in depression: A meta-analysis. Am. J. Epidemiol. 2003, 157, 98-112. [CrossRef] [PubMed]

28. Assari, S.; Caldwell, C.H. High Risk of Depression in High-Income African American Boys. J. Racial Ethn. Health Disparit. 2017, 1-12. [CrossRef] [PubMed]

29. Heeringa, S.; Wagner, J.; Torres, M.; Duan, N.H.; Adams, T.; Berglund, P. Sample designs and sampling methods for the collaborative psychiatric epidemiology studies (CPES). Int. J. Methods Psychiatr. Res. 2004, 13, 221-240. [CrossRef] [PubMed]

30. Kessler, R.C.; Merikangas, K.R. The National Comorbidity Survey Replication (NCS-R): Background and aims. Int. J. Methods Psychiatr. Res. 2004, 13, 60-68. [CrossRef] [PubMed]

31. Alegria, M.; Takeuchi, D.; Canino, G.; Duan, N.; Shrout, P.; Meng, X.; Vega, W.; Zane, N.; Vila, D.; Woo, M.; et al. Considering context, place and culture: The National Latino and Asian American Study. Int. J. Methods Psychiatr. Res. 2004, 13, 208-220. [CrossRef] [PubMed]

32. Kessler, R.C.; Calabrese, J.R.; Farley, P.A.; Gruber, M.J.; Jewell, M.A.; Katon, W.; Keck, P.E.; Nierenberg, A.A.; Sampson, N.A.; Shear, M.K.; et al. Composite International Diagnostic Interview screening scales for DSM-IV anxiety and mood disorders. Psychol. Med. 2013, 43, 1625-1637. [CrossRef] [PubMed]

33. Kessler, R.C.; Wittchen, H.-U.; Abelson, J.M.; McGonagle, K.; Schwarz, N.; Kendler, K.S.; Knäuper, B.; Zhao, S. Methodological studies of the Composite International Diagnostic Interview (CIDI) in the US National Comorbidity Survey. Int. J. Methods Psychiatr. Res. 1998, 7, 33-55. [CrossRef]

34. Robins, L.N.; Wing, J.; Wittchen, H.U.; Helzer, J.E.; Babor, T.F.; Burke, J.; Farmer, A.; Jablenski, A.; Pickens, R.; Regier, D.A.; et al. The Composite International Diagnostic Interview. An epidemiologic instrument suitable for use in conjunction with different diagnostic systems and in different cultures. Arch. Gen. Psychiatry 1988, 45, 1069-1077. [CrossRef] [PubMed] 
35. Williams, D.R.; González, H.M.; Neighbors, H.; Nesse, R.; Abelson, J.M.; Sweetman, J.; Jackson, J.S. Prevalence and distribution of major depressive disorder in African Americans, Caribbean blacks, and nonHispanic whites: Results from the National Survey of American Life. Arch. Gen. Psychiatry 2007, 64, 305-315. [CrossRef] [PubMed]

36. $\mathrm{Hu}, \mathrm{W}$. Reliability and validity studies of the WHO-Composite International Diagnostic Interview (CIDI): A critical review. J. Psychiatr. Res. 1994, 200, 57-84.

37. Kessler, R.C.; Neighbors, H.W. A new perspective on the relationships among race, social class, and psychological distress. J. Health Soc. Behav. 1986, 27, 107-115. [CrossRef] [PubMed]

38. Assari, S. Chronic Medical Conditions and Major Depressive Disorder: Differential Role of Positive Religious Coping among African Americans, Caribbean Blacks and Non-Hispanic Whites. Int. J. Prev. Med. 2014, 5, 405-413. [PubMed]

39. Assari, S. Number of Chronic Medical Conditions Fully Mediates the Effects of Race on Mortality; 25-Year Follow-Up of a Nationally Representative Sample of Americans. J. Racial Ethn. Health Disparit. 2017, 4, 623-631. [CrossRef] [PubMed]

40. Assari, S.; Lankarani, M.M. Chronic Medical Conditions and Negative Affect; Racial Variation in Reciprocal Associations over Time. Front. Psychiatry 2016, 7, 140. [CrossRef] [PubMed]

41. Spencer, E.A.; Appleby, P.N.; Davey, G.K.; Key, T.J. Validity of self-reported height and weight in 4808 EPIC-Oxford participants. Public Health Nutr. 2002, 5, 561-565. [CrossRef] [PubMed]

42. Stewart, A.L. The reliability and validity of self-reported weight and height. J. Chronic Dis. 1982, 35, $295-309$. [CrossRef]

43. Chou, T.; Asnaani, A.; Hofmann, S.G. Perception of racial discrimination and psychopathology across three U.S. ethnic minority groups. Cult. Divers. Ethn. Minor. Psychol. 2012, 18, 74-81. [CrossRef] [PubMed]

44. Asnaani, A.; Richey, J.A.; Dimaite, R.; Hinton, D.E.; Hofmann, S.G. A cross-ethnic comparison of lifetime prevalence rates of anxiety disorders. J. Nerv. Ment. Dis. 2010, 198, 551-555. [CrossRef] [PubMed]

45. Asnaani, A.; Gutner, C.A.; Hinton, D.E.; Hofmann, S.G. Panic disorder, panic attacks and panic attack symptoms across race-ethnic groups: Results of the collaborative psychiatric epidemiology studies. CNS Neurosci. Ther. 2009, 15, 249-254. [CrossRef] [PubMed]

46. Gavin, A.R.; Walton, E.; Chae, D.H.; Alegria, M.; Jackson, J.S.; Takeuchi, D. The associations between socio-economic status and major depressive disorder among Blacks, Latinos, Asians and non-Hispanic Whites: Findings from the Collaborative Psychiatric Epidemiology Studies. Psychol. Med. 2010, 40, 51-61. [CrossRef] [PubMed]

47. Lampe, F.C.; Walker, M.; Lennon, L.T.; Whincup, P.H.; Ebrahim, S. Validity of a self-reported history of doctor-diagnosed angina. J. Clin. Epidemiol. 1999, 52, 73-81. [CrossRef]

48. Assari, S.; Lankarani, M.M.; Burgard, S. Black-white difference in long-term predictive power of self-rated health on all-cause mortality in United States. Ann. Epidemiol. 2016, 26, 106-114. [CrossRef] [PubMed]

49. Assari, S.; Burgard, S.; Zivin, K. Long-term reciprocal associations between depressive symptoms and number of chronic medical conditions: Longitudinal support for black-white health paradox. J. Racial Ethn. Health Disparit. 2015, 2, 589-597. [CrossRef] [PubMed]

50. Assari, S.; Moazen-Zadeh, E.; Lankarani, M.M.; Micol-Foster, V. Race, depressive symptoms, and all-cause mortality in the United States. Front. Public Health 2016, 4, 40. [CrossRef] [PubMed]

51. Assari, S.; Lankarani, M.M. Depressive symptoms are associated with more hopelessness among white than black older adults. Front. Public Health 2016, 4, 82. [CrossRef] [PubMed]

52. Assari, S.; Burgard, S. Black-White differences in the effect of baseline depressive symptoms on deaths due to renal diseases: 25 year follow up of a nationally representative community sample. J. Ren. Inj. Prev. 2015, 4, 127-134. [PubMed]

53. Assari, S. Hostility, anger, and cardiovascular mortality among Blacks and Whites. Res. Cardiovasc. Med. 2016. [CrossRef]

54. Assari, S. Race, sense of control over life, and short-term risk of mortality among older adults in the United States. Arch. Med. Sci. 2016. [CrossRef] [PubMed]

55. Assari, S.; Lankarani, M.M. Association between stressful life events and depression; intersection of race and gender. J. Racial Ethn. Health Disparit. 2016, 3, 349-356. [CrossRef] [PubMed] 
56. Assari, S.; Sonnega, A.; Pepin, R.; Leggett, A. Residual effects of restless sleep over depressive symptoms on chronic medical conditions: Race by gender differences. J. Racial Ethn. Health Disparit. 2016. [CrossRef] [PubMed]

57. Assari, S. Perceived neighborhood safety better predicts 25-year mortality risk among Whites than Blacks. J. Racial Ethn. Health Disparit. 2016. [CrossRef]

58. Chen, E.; Martin, A.D.; Matthews, K.A. Understanding health disparities: The role of race and socioeconomic status in children's health. Am. J. Public Health 2006, 96, 702-708. [CrossRef] [PubMed]

59. Dowd, J.J.; Bengtson, V.L. Aging in minority populations an examination of the double jeopardy hypothesis. J. Gerontol. 1978, 33, 427-436. [CrossRef] [PubMed]

60. Wilson, K.B.; Thorpe, R.J.; LaVeist, T.A. Dollar for dollar: Racial and ethnic inequalities in health and health-related outcomes among persons with very high income. Prev. Med. 2017, 96, 149-153. [CrossRef] [PubMed]

61. Bowleg, L.; Huang, J.; Brooks, K.; Black, A.; Burkholder, G. Triple jeopardy and beyond: Multiple minority stress and resilience among Black lesbians. J. Lesbian Stud. 2003, 7, 87-108. [CrossRef] [PubMed]

62. King, D.K. Multiple jeopardy, multiple consciousness: The context of a Black feminist ideology. Signs J. Women Cult. Soc. 1988, 14, 42-72. [CrossRef]

63. Hayward, M.D.; Hummer, R.A.; Sasson, I. Trends and group differences in the association between educational attainment and U.S. adult mortality: Implications for understanding education's causal influence. Soc. Sci. Med. 2015, 127, 8-18. [CrossRef] [PubMed]

64. Backlund, E.; Sorlie, P.D.; Johnson, N.J. A comparison of the relationships of education and income with mortality: The national longitudinal mortality study. Soc. Sci. Med. 1999, 49, 1373-1384. [CrossRef]

65. Everett, B.G.; Rehkopf, D.H.; Rogers, R.G. The nonlinear relationship between education and mortality: An examination of cohort, race/ethnic, and gender differences. Popul. Res. Policy Rev. 2013, 32, 893-917. [CrossRef] [PubMed]

66. Cutler, D.M.; Lleras-Muney, A. Education and Health: Evaluating Theories and Evidence. National Bureau of Economic Research. Available online: http://www.nber.org/papers/w12352/ (accessed on 9 September 2017).

67. Holmes, C.J.; Zajacova, A. Education as "the great equalizer": Health benefits for black and white adults. Soc. Sci. Q. 2014, 95, 1064-1085. [CrossRef]

68. Assari, S.; Nikahd, A.; Malekahmadi, M.R.; Lankarani, M.M.; Zamanian, H. Race by gender group differences in the protective effects of socioeconomic factors against sustained health problems across five domains. J. Racial Ethn. Health Disparit. 2017, 4, 884-894. [CrossRef] [PubMed]

69. Oliver, M.L.; Shapiro, T.M. Black Wealth, White Wealth: A New Perspective on Racial Inequality; Taylor \& Francis: Abingdon, UK, 2006.

70. Williams, D.R.; Collins, C. Racial residential segregation: A fundamental cause of racial disparities in health. Public Health Rep. 2001, 116, 404-416. [CrossRef]

71. Williams, D.R.; Mohammed, S.A.; Leavell, J.; Collins, C. Race, socioeconomic status, and health: Complexities, ongoing challenges, and research opportunities. Ann. N. Y. Acad. Sci. 2010, 1186, 69-101. [CrossRef] [PubMed]

72. Assari, S.; Caldwell, C.H. Social Determinants of Perceived Discrimination among Black Youth: Intersection of Ethnicity and Gender. Children 2018, 5, 24. [CrossRef] [PubMed]

73. Navarro, V. Race or class, or race and class. Int. J. Health Serv. 1989, 19, 311-314. [CrossRef] [PubMed]

74. Mehta, N.; Preston, S. Are major behavioral and sociodemographic risk factors for mortality additive or multiplicative in their effects? Soc. Sci. Med. 2016, 154, 93-99. [CrossRef] [PubMed]

75. Williams, D.R.; Collins, C.U.S. socioeconomic and racial differences in health: Patterns and explanations. Ann. Rev. Sociol. 1995, 21, 349-386. [CrossRef]

76. Farmer, M.M.; Ferraro, K.F. Are racial disparities in health conditional on socioeconomic status? Soc. Sci. Med. 2005, 60, 191-204. [CrossRef] [PubMed]

77. Assari, S.; Moazen-Zadeh, E. Ethnic Variation in the Cross-sectional Association between Domains of Depressive Symptoms and Clinical Depression. Front. Psychiatry 2016, 7, 53. [CrossRef] [PubMed]

(C) 2018 by the author. Licensee MDPI, Basel, Switzerland. This article is an open access article distributed under the terms and conditions of the Creative Commons Attribution (CC BY) license (http:/ / creativecommons.org/licenses/by/4.0/). 